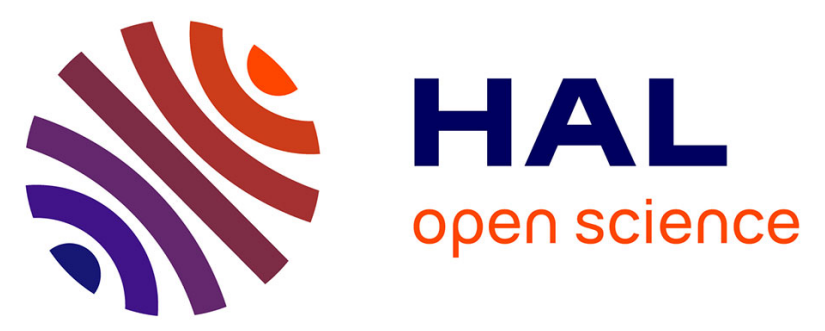

\title{
Assessment of Coralline Species Diversity in the European Coasts Supported by Sequencing of Type Material: The Case Study of Lithophyllum nitorum (Corallinales, Rhodophyta)
}

Viviana Pena, Jazmin J Hernandez-Kantun, Walter H Adey, Line Le Gall

\section{To cite this version:}

Viviana Pena, Jazmin J Hernandez-Kantun, Walter H Adey, Line Le Gall. Assessment of Coralline Species Diversity in the European Coasts Supported by Sequencing of Type Material: The Case Study of Lithophyllum nitorum (Corallinales, Rhodophyta). Cryptogamie Algologie, 2018, 39 (1), pp.123 137. $10.7872 /$ crya/v39.iss1.2018.123 . hal-01787113

\section{HAL Id: hal-01787113 \\ https://hal.sorbonne-universite.fr/hal-01787113}

Submitted on 7 May 2018

HAL is a multi-disciplinary open access archive for the deposit and dissemination of scientific research documents, whether they are published or not. The documents may come from teaching and research institutions in France or abroad, or from public or private research centers.
L'archive ouverte pluridisciplinaire HAL, est destinée au dépôt et à la diffusion de documents scientifiques de niveau recherche, publiés ou non, émanant des établissements d'enseignement et de recherche français ou étrangers, des laboratoires publics ou privés. 
Assessment of coralline species diversity in the European coasts supported by sequencing of type material: the case study of Lithophyllum nitorum (Corallinales, Rhodophyta).

Viviana PEÑA ${ }^{a, b}$, Jazmin J. HERNANDEZ-KANTUN ${ }^{c}$, Walter H. ADEY $Y^{c}$, \& Line LE $G A L L^{b}$

${ }^{a}$ BIOCOST Research Group \& CICA, Universidade da Coruña, Campus de A Coruña, 15071, A Coruña, Spain.

${ }^{\mathrm{b}}$ Equipe Exploration, Espèces et Evolution, Institut de Systématique, Evolution, Biodiversité, UMR 7205 ISYEB CNRS, MNHN, UPMC, EPHE, Muséum national d'Histoire naturelle (MNHN), Sorbonne Universités, 57 rue Cuvier CP N39, F-75005, Paris, France.

c Botany Department, National Museum of Natural History, Smithsonian Institution, MRC 166 PO Box 37012, Washington, D.C., USA.

Corresponding author: Viviana Peña. Email address: vpena@udc.es.

Running title: Lithophyllum nitorum in the European coasts 


\section{Abstract}

A constant effort in sequencing an extensive number of specimens originating from comprehensive sampling had return an unprecedented amount of information fostering our understanding of diversity, evolution and distribution of coralline algae; however, many sequences lack reliable assignation of a taxonomic name, specially at the species level. Recently, the sequencing of type material allowed to bridge this gap by providing a direct link between the DNA sequence and the type bearing name. For instance, in the genus Lithophyllum, the identity of three species, generally abundant along the European Atlantic and the Mediterranean, was demonstrated by including sequences of the type material. Nevertheless, for less conspicious species, such as Lithophyllum nitorum, data are still needed to assess distribution, anatomy, phylogenetic affinities and taxonomic status. Using DNA sequences recovered from the type material of $L$. nitorum, further recent collections were resolved as conspecific and used to improve the description and refine the distribution of this species. Lithophyllum nitorum consisted of subtidal, thin crusts overgrowing fragments of dead maerl, pebbles and drifted fragments of fishing lines. The presence of uniporate conceptacles markedly protruding can be considered an external morphological feature useful to identify L. nitorum from other subtidal Lithophyllum species with similar habitat. Lithophyllum nitorum is reported for the Mediterranean Sea and confirmed in the North East Atlantic, a similar distribution as for L. incrustans and L. hibernicum.

Keywords: Biodiversity, Corallinales, DNA barcoding, distribution, Lithophyllum, maerl beds, Mediterranean, North East Atlantic, systematics, type collections. 


\section{INTRODUCTION}

Lithophyllum Philippi is considered one of the most speciose non-geniculate coralline algal genera with 130 specific/infraspecific names currently accepted (Guiry \& Guiry, 2017). This genus is mainly distributed in tropical and temperate waters, where it contributes to the formation of characteristic calcareous bioconstructions such as the Caribbean algal ridges (Adey, 1978), the coralligenous and trottoir communities in the Mediterranean Sea (Ballesteros, 2006; Pezzolesi et al., 2016), and singular maerl beds in the Norht East Atlantic (Peña et al., 2013; Hernández-Kantún et al., 2015). In this latter region, recent literature pointed out 12 species of Lithophyllum occurring under different growth-forms, from the intertidal to subtidal : the generitype Lithophyllum incrustans Philippi, together with L. bathyporum Athanasiadis \& Ballantine, L. byssoides (Lamarck) Foslie, L. crouaniorum Foslie, L. cystosirae (Hauck) Heydrich, L. decussatum (Ellis \& Solander) Philippi, L. dentatum (Kützing) Foslie, L. hibernicum Foslie, L. nitorum W.H.Adey \& P.J.Adey, L. orbiculatum (Foslie) Foslie, L. papillosum (Zanardini ex Hauck) Foslie and L. vickersiae Me.Lemoine (Chamberlain \& Irvine, 1994; HernandezKantún et al., 2015, reviewed in Lugilde et al., 2016). So far, only three taxa $-L$. incrustans, L. hibernicum and L. bathyporum- have been subject of molecular studies using type material and recent collections from a wide geographic area (HernandezKantun et al., 2015). It allowed a reassessment of the phylogenetic affinities of these species, and the consideration of earlier collections identified as L. duckerae (Cornwall),

L. fasciculatum and L. dentatum (Ireland and Britany) as L. hibernicum and L. incrustans, respectively. These results also demonstrated that $L$. hibernicum and $L$. incrustans have a high morphological plasticity, for which features mainly related with epithallial cells and sporangial conceptacles were useful for their identification (Hernandez-Kantun et al., 2015, Vázquez \& Peña, 2016). A fourth species -L. byssoides- has been also reassessed based on Atlantic and Mediterranean collections; however, molecular information from 
the lectotype (Nullipora byssoides Lamarck) is still pending to be obtained for a better clarification (Pezzolesi et al., 2016).

With regards to the habitat, while the crustose Lithophyllum hibernicum (as L. incrustans in the literature before 2015) and $L$. orbiculatum are common in the intertidal, and $L$. crouaniorum in the subtidal (Adey \& Adey, 1973; Chamberlain et al., 1988, 1991; Chamberlain \& Irvine, 1994), L. nitorum is considered a rare species, occurring on rock and shells only in the sublittoral zone down to 46 m (Adey \& Adey, 1973; Chamberlain \& Irvine, 1994). Lithophyllum nitorum was described by Adey \& Adey (1973), and it was mainly characterized by small, adherent crusts relatively thin, with orange- pink colour, a smooth surface without orbital ridges, highly to somewhat glossy, a single layer of epithallial cells (rarely two), short subepithallial cells, cortical cells of contiguous filaments usually laterally aligned, conceptacles markedly protruding, usually bisporangial with a pore canal tapering to the surface and lined by small papillae, and sporangial chambers not globular with a small columella (Adey \& Adey, 1973; Chamberlain \& Irvine, 1994). In addition, Chamberlain \& Irvine (1994) pointed out the absence of secondary growth and growth over Lithothamnion sonderi Hauck as key characters to identify plants of $L$. nitorum in the British Isles. The type locality of $L$. nitorum is Port Erin Harbour (Isle of Man, 3-9 m depth, as epilithic in Adey \& Adey, 1973), but it was also reported southwards to northern Spain (Chamberlain \& Irvine, 1994); in fact, Adey \& Adey (1973) recorded L. nitorum at most of the Bay of Biscay stations sampled, reaching 24\% abundance at 37-46 m off Castro Urdiales (Cantabrian Sea) compared to $14 \%$ between $8-30 \mathrm{~m}$ in the British Isles, particularly abundant off the Lizard (Cornwall) while it occurrs sporadically northwards (ca. 0.2-0.7 \% mean abundance, fig. 53 in Adey \& Adey, 1973). In the Mediterranean Spain, Braga \& Aguirre (1995) observed plants attributed to L. nitorum in Almería and in Cabrera (Balearic Islands), and reported it in southern Spain as minor component of fossil coralline associations in the Neogene (Miocene and Pliocene, ca. 23 million years ago).

With the aim of re-assessing coralline species diversity and distributions along the 
European coasts, the sequencing of type specimens coupled with extensive sampling across a wide geographic area became the most efficient practice to refine the concept of a species (Puillandre et al., 2011). In the present study, we obtained DNA sequences (psbA and COI-5P) from the holotype of Lithophyllum nitorum, and we inferred species delimitation among recent collections made along the European coasts to assess the distribution of this species.

\section{MATERIAL AND METHODS}

\section{Collections studied}

We examined the holotype of Lithophyllum nitorum, collected in Port Erin Harbour, Isle of Man, at 3-9 m depth (Adey \& Adey, 1973), and preserved in the herbarium of the Smithsonian Institution (US 70-10B, 10-30, Fig. 1). In addition, we studied eleven specimens identified as Lithophyllum sp. collected in recent subtidal surveys in Brittany (Trevignon, Fig. 2), Galicia (Ons and Cíes archipelagos, Islas Atlanticas National Park, Figs 3-7), and Mediterranean Spain (Granada, Figs 8-9) (Table 1). The Atlantic collections corresponded to thin crusts overgrowing dead maerl and pebbles associated to maerl beds between 11-15 m depth in 2011 (Figs 2-7), while the Mediterranean specimens consisted on crusts on a pebble and a drifted fragment of a fishing line at $15 \mathrm{~m}$ depth in 2012 (Figs 8-9). Recent collections were air-dried or oven-dried (50 $\left.{ }^{\circ} \mathrm{C}\right)$, preserved in plastic bags with silica gel before molecular and morphological studies, and deposited in the herbaria of Universidade de Santiago de Compostela (SANT) and Museum National d’Histoire Naturelle (PC) (acronyms follow Thiers, 2015).

\section{DNA sequencing and phylogenetic analyses}

Eleven specimens from recent subtidal collections were cleaned under a stereomicroscope and selected surfaces were ground for DNA extraction. Genomic DNA 
was extracted using a NucleoSpin ${ }^{\circledR} 96$ Tissue kit (Macherey-Nagel, GmbH and Co. KG, Germany), and DNeasy® Blood \& Tissue Kit (Qiagen, Valencia, CA) following manufacture's recommendations. DNA extractions and amplifications of the holotype of Lithophyllum nitorum housed in US were performed separately from recent collections and with negative controls run throughout at Smithsonian Laboratories of Analytical Biology, Washington DC, US; extraction of total genomic DNA of the holotype followed the modified protocol by Broom et al. (2008) of the Qiagen DNeasy Blood and Tissue Kit® (Qiagen, Crawley, UK). The mitochondrial COI-5P fragment was PCR-amplified using primer pairs GazF1/GazR1 (Saunders, 2005). The chloroplast psbA gene was amplified using primer pairs psbA-F1/ psbA-R2 or psbA-F1/psbA600R (Yoon et al., 2002), this latter used for the holotype. PCR reactions, thermal profiles, cleaning for sequencing and sequencing of the resulting products of the holotype followed Adey et al. (2015). Thermal profiles for PCR amplification of COI-5P and psbA fragments of recent collections followed Saunders \& McDevit (2012) and Bittner (2009), respectively; PCR reactions followed Peña et al. (2015a). Excess primers and nucleotides from PCR products (labeled CPVP, Table 1) were removed with shrimp alkaline phosphatase and exonuclease I enzymes, and sequenced using the Sanger method at Macrogen facilities (http://www.macrogen.com). PCR products labelled VPF and LLG (Table 1) were purified and sequenced by Genoscope (Bibliothèque du Vivant program, Centre National de Séquençage, France). Sequences were assembled and aligned with the assistance of CodonCode Aligner ${ }^{\circledR}$ (CodonCode Corporation, USA) and adjusted by eye using SeaView version 4 (Gouy et al., 2010). Sequences were submitted to the Barcode of Life Data Systems (project 'NGCOR', BOLD, http://www.boldsystems.org; Ratnasingham \& Hebert, 2007) and GenBank (accession numbers listed in Table 1). Our analyses also comprised publicly available GenBank sequences of Atlantic and Mediterranean Lithophyllum spp., including those conspecific with type collections of the generitype $L$. incrustans, L. bathyporum and L. hibernicum (Hernández-Kantun et al., 2015) as well as the most relevant matches found with L. nitorum (> 90\% similarity). These databases also 
encompassed sequences assigned to the genus Lithophyllum, and collected as associated crusts in Galician and Brittany maerl beds (Pardo et al., 2017). According to recent phylogenetic studies (Van der Merwe et al., 2015; Rösler et al., 2016), publicly available sequences for Spongites spp. corresponding to the "Southern Hemisphere group” were selected as outgroups for the psbA alignment; while sequences of Porolithon onkodes were selected as outgroups for the COI-5P alignment (Table 1).

The alignments comprised 25 COI-5P and 16 psbA sequences. Phylogenetic relationships were inferred using Maximum Likelihood (ML) and Bayesian inference (BI) using Mega 6 and MrBayes 3.2.1, respectively (Ronquist \& Huelsenbeck, 2003; Tamura et al., 2013). Models of sequence evolution were estimated using the Akaike Information Criterion (AIC) and the Bayesian Information Criterion (BIC) obtained in jModeltest 2.1.3 (Darriba et al., 2012). Maximum Likelihood and Bayesian analyses for the COI-5P and psbA alignments were performed under a generalized time-reversible with gamma+invariant sites heterogeneity model $(G T R+G+I)$. The Bayesian analyses were performed under the same model with four Markov Chain Monte Carlo for 10 million generations, and tree sampling every 1000 generations.

\section{Morphological studies of DNA-sequenced specimens}

According to the previous phylogenetic analyses, representative specimens resolved conspecific to Lithophyllum nitorum were selected for anatomical examination with a scanning electron microscope (SEM, model JEOL JSM 6400, Universidade da Coruña, Spain). The examined specimens were deposited in the herbarium of Universidade de Santiago de Compostela (SANT). Cell length is the distance between primary pitconnections, and cell diameter is the measurement taken perpendicularly to this across the middle of the cell lumen. Conceptacle measurements were taken according to Adey \& Adey (1973) and Chamberlain \& Irvine (1994). 


\section{RESULTS}

The holotype of Lithophyllum nitorum was successfully sequenced only for the plastid psbA gene (fragment of $450 \mathrm{bp}$ ), but it did not result in any match in GenBank database obtaining the highest similarity (94\%) with Lithophyllum impressum from NE Pacific and Uncultured Corallinales -LBC0599- from Vanuatu (Table 1, Fig. 10; searched on 9 November 2017). Our phylogenetic analyses of the psbA alignment (22 sequences ranging from 450 to 822 bp, with 222 variable sites) resolved this species, albeit with low support values, as the sister taxa of $L$. byssoides. Moreover, this phylogeny recovered a recent collection obtained from a Galician maerl bed (voucher SANT-Algae 31426, Ons archipelago) with high similarity with the holotype of L. nitorum (0.07 \% divergence, 3 bp difference, Fig. 10). Based on this recent collection, the phylogenetic tree obtained from the ML analysis of the COI-5P alignment (25 sequences resulting 17 haplotypes, ranging from 445 to 664 bp in length, consisting of 216 variable sites) resolved another ten additonal specimens (grouped into four haplotypes) from Atlantic and Mediterranean waters as conspecific with it (Fig. 11). Thus, our results confirm the occurrence of $L$. nitorum along the Atlantic European coasts of Brittany and the Northwest of the Iberian Peninsula (Galicia), and they also expand its distribution range southwards to the Mediterranean Spain (Granada).

The recent collections resolved conspecific with the holotype of Lithophyllum nitorum (Fig. 1) and consisted of small crusts overgrowing fragments of dead maerl (ca. $<3 \mathrm{~cm}$ ), pebbles, cobbles, and a drifted fragment of fishing line (Figs 2-9). In contrast with the colour features provided in the literautre for L. nitorum, the colour of our specimens was dark to pale pink, and the surface was somewhat glossy only in some specimens (i.e. Fig. 3). Uniporate conceptacles were conspicuously protruding (Figs 12,13) and surrounded by a white rim (i.e. Figs 5,12). The SEM examination of several specimens showed very thin crusts, $<500 \mu \mathrm{m}$ thick, very adherent to the substrate with a monomerous construction and non-coaxial medulla (Fig. 14). Epithallial cells were mostly flattened, 1- 
$2 \mu \mathrm{m}$ tall x 7-8 $\mu \mathrm{m}$ diameter, disposed in 1-2 layers. Subepithallial cells were 5-8 $\mu \mathrm{m}$ tall x 3-10 $\mu$ m diameter, as short as or shorter than cells subtending them (Figs 16, 17). Cortical cells of contiguous filaments were laterally aligned, 6-14 $\mu \mathrm{m}$ tall x 5-8 $\mu \mathrm{m}$ diameter, containing inclusions usually interpreted as floridean starch (Figs 15-17). Secondary pit-connections were observed; cell fusions were absent (Fig. 15). Uniporate conceptacles were protruding (Fig. 18); old conceptacles were buried, not infilled, with elliptical chambers of 54-100 $\mu \mathrm{m}$ in height x 180-290 $\mu \mathrm{m}$ in diameter (Fig. 22).

According to the shape of the chamber, some buried and empty conceptacles in one plant collected in Ons archipelago (Galicia, voucher SANT-Algae 31426) corresponded to spermatangial conceptacles with chambers $21-22 \mu \mathrm{m}$ in height $\mathrm{x} 84-87 \mu \mathrm{m}$ in diameter (Fig. 19). While another recent collection from the same Galician locality (voucher SANT-Algae 31421) showed an uniporate tetrasporangial conceptacle protruding (Fig. 20), with pore canal of $50 \mu \mathrm{m}$ in length, tapering towards the surface (from $60 \mu \mathrm{m}$ to 20 $\mu \mathrm{m}$ diameter) (Fig. 21); the chamber was $150 \mu \mathrm{m}$ in height x $250 \mu \mathrm{m}$ in diameter , with a small calcified columella and tetrasporangia elongate, $117 \mu \mathrm{m}$ in height x $24 \mu \mathrm{m}$ in diameter, zonately divided (Fig. 20).

\section{DISCUSSION}

Based on a phylogenetic analysis of $p s b$ A sequences including the sequence obtained for the holotype of Lithophyllum nitorum, we were able to identify conspecific specimens in our recent collections from Atlantic and Mediterranean coasts (Fig. 11). However, none of the publicly available sequences from recent studies in Atlantic and Mediterranean Lithophyllum taxa (i.e. Hernández-Kantún et al., 2015; Pezzolesi et al., 2016; Pardo et al., 2017) matched sequences from L. nitorum. According to the literature (Adey \& Adey, 1973; Chamberlain \& Irvine, 1994), Lithophyllum nitorum is considered a rare, subtidal species distributed from the British Isles to northern Spain, and recorded on rocks and shells. Our present study based on DNA sequence data confirmed the presence of 
Lithophyllum nitorum in Brittany, the Northwest of the Iberian Peninsula (Galicia) and Mediterranean Spain. Furthermore, this study revealed the presence of this species on other substrates such as dead maerl, small pebbles or even drifted fragments of fishing lines. It is noteworthy to remark that all specimens collected are of small size and do not develop into large, conspicuous crusts; therefore, L. nitorum is likely to be easily overlooked. In agreement with the literature reports (Adey \& Adey, 1973; Chamberlain \& Irvine, 1994) and our morphological observations, the presence of uniporate conceptacles markedly protruding can be considered an external morphological feature useful to identify L. nitorum from other Lithophyllum species that also occur in the subtidal, such as L. crouaniorum, L. bathyporum, L. hibernicum or L. incrustans (Chamberlain \& Irvine, 1994; Hernández-Kantún et al., 2015). On the other hand, L. nitorum is described in the literature as orange- pink crusts, highly to somewhat glossy (Adey \& Adey, 1973; Chamberlain \& Irvine, 1994) while in our collections the colour varied from dark to pale pink and only some specimens were somewhat glossy. Most of our specimens of $L$. nitorum have empty uniporate conceptacles, but one Galician plant is considered a male gametophyte based on the shape of spermatangial conceptacles. Chamberlain \& Irvine (1994) pointed out that gametangial plants are unknown in the British Isles; Adey \& Adey (1973, Table XII) recorded spermatangial conceptacles, however collection details are not indicated. According to the measurements provided in Adey \& Adey (1973), the Galician specimen had smaller chambers (21-22 $\mu \mathrm{m}$ in height x 84-87 $\mu \mathrm{m}$ in diameter vs. $22 \mu \mathrm{m}$ in height $\mathrm{x}$ 90-118 $\mu \mathrm{m}$ in diameter). In our study, only one Galician specimen examined showed tetrasporangial conceptacles that are in agreement with the literature (chamber $150 \mu \mathrm{m}$ in height x $250 \mu \mathrm{m}$ in diameter vs 100-135 x 255-385 $\mu \mathrm{m} \mu \mathrm{m}$ and 94$156 \mu \mathrm{m}$ x 245-385 $\mu \mathrm{m}$ in Adey \& Adey, 1973 and Chamberlain \& Irvine, 1994, respectively). For the British Isles, Chamberlain \& Irvine (1994) reported only bisporangial conceptacles, while Adey \& Adey (1973) indicated that tetrasporangia were rare in the distribution range hitherto known for $L$. nitorum along the Atlantic European coasts. Likewise, we observed buried conceptacles not infilled which has not been 
reported earlier (Adey \& Adey, 1973; Chamberlain \& Irvine, 1994). The distribution range hitherto reported for L. nitorum is restricted from the British Isles to northern Spain (Adey \& Adey, 1973; Chamberlain \& Irvine, 1994); our results confirm records for Brittany and Galicia (Northwest of Spain), and they also expand the distribution of the species southwards to the Spanish coast of the Mediterranean Sea (Granada). Our Mediterranean record based on molecular evidences are congruent with previous observations of extant plants and Neogene fossil records in southern Spain and Balearic Islands (Braga \& Aguirre, 1995). All recent collections assigned to L. nitorum were subtidal, made between 11-15 m, in agreement with the wide depth range provided in the literature (3-30 m in the British Isles, down to 46 m in northern Spain, Adey \& Adey, 1973; Chamberlain \& Irvine, 1994). The Atlantic collections from Brittany and Galicia were found on dead maerl or small pebbles associated with maerl beds. A recent DNA barcoding study carried out on maerl beds from these two Atlantic regions (Pardo et al., 2017) revealed higher species diversity in associated crustose coralline algae than in maerl-forming species ( 9 vs 3, as total taxa obtained for each growth-form); two out of the nine crustose taxa corresponded to Lithophyllum hibernicum (Brittany) and an unidentified Lithophyllum sp.3 (Galicia) overgrowing pebbles, both with uniporate conceptacles not protruding (Fig. 3 in Pardo et al., 2017). The record of L. nitorum as an additional encrusting species associated with maerl beds in Brittany and Galicia increases the associated diversity reported for this coastal habitat in the North East Atlantic (Peña et al., 2014a).

The present work confirms the effectiveness of sequencing type specimens of coralline algae to link the type bearing name to the many sequences obtained from recent specimens (i.e. Peña et al. 2014b, 2015b; Adey et al., 2015; Hernandez-Kantun et al., 2015) in the aim to establish a DNA Library of Life (Le Gall et al., 2017). The sequence of the holotype of Lithophyllum nitorum allowed us to identify recent collections that expanded its distribution range southwards to the Mediterranean. Lithophyllum nitorum is 
considered a rare species in the British Isles, while our results indicate that it occurs on different substrates in the subtidal, even associated to maerl beds in Brittany and Galicia. According to the literature (Adey \& Adey 1973), L. nitorum occurs sporadically to the north while increased southwards in Cornwall and the Cantabrian Sea. Together with our confirmed records in the Northwest of Spain (Galicia) and in the Mediterranean, it might represent a temperate Lithophyllum species with warm-water affinities; a similar AtlanticMediterranean distribution is also reported for $L$. incrustans and $L$. hibernicum (Hernández-Kantún et al., 2015). Despite the considerable number of publicly available sequences of Lithophyllum taxa (more than 275 COI-5P and psbA GenBank sequences), none of them matched with L. nitorum; the presence of this uncommon, subtidal species with somewhat restricted distribution further supports Lithophyllum as a genetically diverse genus in the European coasts (i.e. Pezzolesi et al., 2016). In this regard, if the diversification of the subfamily Lithophylloideae was estimated during the early and middle Miocene ( 23-12 million years ago, Rösler et al., 2017), the Miocene fossil records of L. nitorum in Mediterranean Spain (Braga \& Aguirre, 1995) would indicate an early divergence of this species. Finally, our results based on type material confirmed Lithophyllum nitorum as a distinct species from other European Lithophyllum taxa recently re-assessed (Hernández-Kantun et al., 2015). Numerous additional Lithophyllum species from the North East Atlantic and worldwide need to have their type specimens sequenced to correctly apply names.

\section{Acknowledgments}

Financial support came from the following institutions and projects: Action Transversale du Muséum National d’Histoire Naturelle (“Taxonomie moléculaire: DNA Barcode et gestion durable des collections" and "Biodiversité actuelle et fossile. Crises, stress, restaurations et panchronisme: le message systématique” and “Emergences”), Spain's 
Ministerio de Economía y Competitividad (CTM2010-18787, partially founded by FEDER) and Xunta de Galicia (10MMA103003PR); ASSEMBLE (grant agreement $\mathrm{n}^{\circ}$. 227799) supported sampling in Brittany. Acquisition of molecular data was carried out at the CNRS-UMS 2700 in Service de Systématique Moléculaire (MNHN, Paris). VPF acknowledges support by Universidade da Coruña (Contrato programa-Campus Industrial de Ferrol). JJHK acknowledges support from the Smithsonian Institution through a postdoctoral fellowship. We sincerely thank Ignacio Bárbara, Rodolfo Barreiro and Cristina Pardo for fieldwork and/or lab collaboration. We acknowledge to Parque Nacional Marítimo Terrestre das Illas Atlánticas de Galicia for permission to carry out our surveys. We are also grateful to both reviewers for their helpful comments on the manuscript.

\section{REFERENCES}

ADEY W.H., 1978 - Algal ridges of the Caribbean Sea and West Indies. Phycologia 17: 361-67.

ADEY W.H. \& ADEY P.J., 1973 - Studies on the biosystematics and ecology of epilithic crustose Corallinaceae of the British Isles. British Phycological Journal 8: 343-407.

ADEY W.H., HERNÁNDEZ-KANTÚN J.J., JOHNSON G. \& GABRIELSON P.W., 2015 - DNA sequencing, anatomy, and calcification patterns support a monophyletic, sub- arctic, carbonate reef-forming Clathromorphum (Hapalidiaceae, Corallinales, Rhodophyta). Journal of Phycology 51: 189-203.

BALLESTEROS E., 2006 - Mediterranean coralligenous assemblages: a synthesis of present knowledge. Oceanography and Marine Biology, Annual Review 44: 123-95.

BASSO D., CARAGNANO A., LE GALL L., \& RODONDI G., 2015 - The genus Lithophyllum in the north-western Indian Ocean, with description of L. yemenense sp. nov., $L$. socotraense sp. nov., $L$. subplicatum comb. et stat. nov., and the resumed $L$. affine, L. kaiseri, and L. subreduncum (Rhodophyta, Corallinales). Phytotaxa 208: 183-200. 
BITTNER L., 2009 - Phylogénie des Corallinales (Rhodophyta) et analyse de leur diversité génétique dans le Pacifique Sud. PhD Thesis, Muséum National d’Histoire Naturelle, Paris.

BRAGA J.C. \& AGUIRRE J., 1995 - Taxonomy of fossil coralline algal species: Neogene Lithophylloideae (Rhodophyta, Corallinaceae) from southern Spain. Review of Palaeobotany and Palynology 86: 265-85.

BROOM J., HART D.R., FARR T., NELSON W., NEILL K., HARVEY A. \& WOELKERLING W., 2008 - Utility of psbA and nSSU for phylogenetic recontruction in the Corallinales based on New Zealand taxa. Molecular Phylogenetics and Evolution 46: 958-73.

CHAMBERLAIN Y.M., IRVINE L.M. \& WALKER R., 1988 - A redescription of Lithophyllum crouanii (Rhodophyta, Corallinales) in the British Isles with and assessment of its relationship to L. orbiculatum. British Phycological Journal 23: 17792.

CHAMBERLAIN Y.M., IRVINE L.M. \& WALKER R., 1991 - A redescription of Lithophyllum orbiculatum (Rhodophyta, Corallinales) in the Britis Isles and areassessment of generic delimitation i the Lithophylloideae. British Phycological Journal 26: 149-67.

CHAMBERLAIN Y.M. \& IRVINE L.M., 1994 - Melobesioideae Bizzozero. In: Seaweeds of the British Isles. Volume 1. Rhodophyta Part 2B Corallinales, Hildenbrandiales. (Irvine, L.M. \& Chamberlain, Y.M. Eds), pp. 159-234. London: HMSO.

DARRIBA D., TABOADA G.L., DOALLO R. \& POSADA D., 2012 - jModelTest 2: more models, new heuristics and parallel computing. Nature Methods 9: 772.

GOUY M., GUINDON S. \& GASCUEL O., 2010 - SeaView Version 4: a multiplatform graphical user interface for sequence alignment and phylogenetic tree building. Molecular Biology and Evolution 27: 221-4.

GUIRY M.D. \& GUIRY G.M., 2017 - AlgaeBase. World-wide electronic publication, 
National University of Ireland, Galway. http://www.algaebase.org; searched on 08 June 2017.

HERNÁNDEZ-KANTÚN J, RINDI F., ADEY W., HEESCH S., PEÑA V., LE GALL L. \& GABRIELSON P.W., 2015 - Sequencing type material resolves the identity and distribution of the generitype Lithophyllum incrustans, and related European species L. hibernicum and L. bathyporum. (Corallinales, Rhodophyta). Journal of Phycology 51: 791-807.

HERNÁNDEZ-KANTÚN J., GABRIELSON P., HUGHEY J., PEZZOLESI L., RINDI F., ROBINSON N., PEÑA V., RIOSMENA-RODRIGUEZ R., LE GALL L. \& ADEY W., 2016 - Reassessment of branched Lithophyllum spp. (Corallinales, Rhodophyta) in the Caribbean Sea with global implications. Phycologia 55: 619-39.

LE GALL L., DELSUC F., HOURDEZ S., LECOINTRE G. \& RASPLUS J-Y., 2017 Toward the DNA Library of Life. European Journal of Taxonomy 266: 1-9.

LUGILDE J., PEÑA V. \& BÁRBARA I., 2016 - El orden Corallinales sensu lato (Rhodophyta) en el Atlántico Ibérico: estado actual de su conocimiento. Anales del Jardín Botánico de Madrid 73: e038 2016.

PARDO C., BÁRBARA I., BARREIRO R. \& PEÑA V., 2017 - Insights into species diversity of associated crustose coralline algae (Corallinophycidae, Rhodophyta) with Atlantic European maerl beds using DNA barcoding. Anales del Jardín Botánico de Madrid. In press.

PEÑA V, BARREIRO R, HALL-SPENCER J.M. \& GRALL J., 2013 - Lithophyllum spp. form unusual maerl beds in the North East Atlantic: the case study of $L$. fasciculatum (Lamarck) Foslie, 1898, in Brittany. An Aod - les cahiers naturalistes de l’Observatoire marin 2: 11-21.

PEÑA V, BARBARA I., GRALL J., MAGGS C.A \& HALL-SPENCER J.M., 2014a The diversity of seaweeds on maerl in NE Atlantic. Marine Biodiversity 4: 533-51. 
PEÑA V., HERNANDEZ-KANTUN J.J., GRALL J., PARDO C., LÓPEZ L.,

BÁRBARA I., LE GALL L. \& BARREIRO R., 2014b- Detection of gametophytes in the maerl-forming species Phymatolithon calcareum (Melobesioideae, Corallinales) assessed by DNA barcoding. Cryptogamie, Algologie 35: 15-25.

PEÑA V., DE CLERCK O., AFONSO-CARRILLO J., BALLESTEROS E., BÁRBARA I., BARREIRO R. \& LE GALL L., 2015a - An integrative systematic approach to species diversity and distribution in the genus Mesophyllum (Corallinales, Rhodophyta) in Atlantic and Mediterranean Europe. European Journal of Phycology 50: 20-36.

PEÑA V., PARDO C., LÓPEZ L., CARRO B., HERNANDEZ-KANTUN J.J., ADEY W.H., BÁRBARA I., BARREIRO R. \& LE GALL L., 2015b - Phymatolithon lusitanicum sp. nov. (Hapalidiales, Rhodophyta): the third most abundant maerlforming species in the Atlantic Iberian Peninsula. Cryptogamie, Algologie 36: 429-59. PEZZOLESI L., FALACE A., KALEB S., HERNÁNDEZ-KANTÚN J.J., CERRANO C. \& RINDI F., 2016 - Genetic and morphological variation in an ecosystem engineer, Lithophyllum byssoides (Corallinales, Rhodophyta). Journal of Phycology 53: 146-60.

\section{PUILLANDRE N., MACPHERSON E., LAMBOURDIÈRE J., CRUAUD C.,} COULOUX A., BOISSELIER-DUBAYLE M-C. \& SAMADI S., 2011. - Barcoding type specimens helps to identify synonyms and an unnamed new species in Eumunida Smith, 1883 (Decapoda: Eumunididae). Invertebrate Systematics 25: 322-333.

RATNASINGHAM S. \& HEBERT P.D.N., 2007 - BOLD: The Barcode of Life Data System (www.barcodinglife.org). Molecular Ecology Notes 7: 355-64.

RICHARDS J.L., GABRIELSON P.W. \& FREDERICQ S., 2014 - New insights into the genus Lithophyllum (Lithophylloideae, Corallinaceae, Corallinales) from deepwater rhodolith beds offshore the NW Gulf of Mexico. Phytotaxa 190: 162-175.

RONQUIST F. \& HUELSENBECK J.P., 2003 - MRBAYES 3: Bayesian phylogenetic 
inference under mixed models. Bioinformatics 19: 1572-74.

RÖSLER A., PERFECTTI F., PEÑA V. \& BRAGA J.C., 2016. - Phylogenetic relationships of Corallinaceae (Corallinales, Rhodophyta): taxonomic implications for reef-building corallines. Journal of Phycology 52: 412-31.

RÖSLER A., PERFECTTI F., PEÑA V., AGUIRRE J. \& BRAGA J.C. 2017 - Timing of the evolutionary history of Corallinaceae (Corallinales, Rhodophyta). Journal of Phycology 53: 567-76.

SAUNDERS G.W., 2005 - Applying DNA barcoding to red macroalgae: a preliminary appraisal holds promise for future applications. Philosophical Transactions of the Royal Society B 360: 1879-88.

SAUNDERS G.W. \& MCDEVIT D.C., 2012 - Methods for DNA barcoding photosynthetic protists emphasizing the macroalgae and diatoms. In DNA Barcodes: Methods and Protocols (Kress,W.J. \& Erickson, D.L., editors), 207-222. Humana Press, New York.

TAMURA K., STECHER G., PETERSON D., FILIPSKI A. \& KUMAR S., 2013 MEGA6: Molecular Evolutionary Genetics Analysis version 6.0. Molecular Biology and Evolution 30: 2725-29.

THIERS B., 2015 - Index Herbariorum: A global directory of public herbaria and associated staff. New York Botanical Garden’s Virtual Herbarium. http://sweetgum.nybg.org/ih/. Revised June 2017.

VAN DER MERWE E., MIKLASZ K., CHANNING A., MANEVELDT G.W. \& GABRIELSON P.W., 2015 - DNA sequencing resolves species of Spongites (Corallinales, Rhodophyta) in the Northeast Pacific and South Africa, including S. agulhensis sp. nov. Phycologia 54: 471-90.

VÁZQUEZ R. \& PEÑA V., 2016 - Tipo de división en esporocistes de Lithophyllum hibernicum (Corallinales, Rhodophyta) y su implicación en el ciclo vital, en el Atlántico europeo. Nova Acta Científica Compostelana, Bioloxía 23: 99-106. 
YOON S.H., HACKETT J.D. \& BHATTACHARYA D., 2002 - A single origin of the peridinin- and fucoxanthin-containing plastids in dinoflagellates through tertiary endosymbiosis. Proceedings of the National Academy of Sciences USA 99: 11724-9. 
Table 1. Sample information for species included in molecular analyses. In bold, holotype specimen of Lithophyllum nitorum. Additional COI-5P and psbA sequences downloaded from GenBank are detailed.

\begin{tabular}{|c|c|c|c|c|c|}
\hline Species & Voucher & $\begin{array}{c}\text { GenBank } \\
\text { accession } \\
\text { number (COI- } \\
5 P)\end{array}$ & $\begin{array}{c}\text { GenBank } \\
\text { accession } \\
\text { number } \\
\text { (psbA) }\end{array}$ & Collection details & Herbarium \\
\hline Lithophyllum nitorum & US 70-10B & & MG648773 & $\begin{array}{l}\text { Port Erin Harbour, Isle of Man, UK (Adey } \\
\text { \& Adey, 1973) }\end{array}$ & US 70-10B \\
\hline L. nitorum & CPVP913 & MG648771 & & $\begin{array}{l}\text { Subtidal (15 m), maerl bed, Le Dragon, } \\
\text { Trevignon, France, 13/05/2011. Coll. W. } \\
\text { Thomas, Y. Fontana. }\end{array}$ & SANT-Algae 31427 \\
\hline L. nitorum & CPVP760 & MG648763 & & $\begin{array}{l}\text { Subtidal (13 m), maerl bed, Ons, Ría de } \\
\text { Pontevedra, Galicia, Spain, 07/04/2011. Coll. } \\
\text { I. Bárbara, R. Barreiro, V. Peña. }\end{array}$ & SANT-Algae 31420 \\
\hline
\end{tabular}


CPVP772

\section{MG648765}

CPVP774

MG648767

VPF00474

MG648769

VPF00475
MG648762
Subtidal (13 m), maerl bed, Ons, Ría de

SANT-Algae 31421

Pontevedra, Galicia, Spain, 07/04/2011. Coll.

I. Bárbara, R. Barreiro, V. Peña.

Subtidal (13 m), maerl bed, Ons, Ría de

SANT-Algae 31422

Pontevedra, Galicia, Spain, 07/04/2011. Coll.

I. Bárbara, R. Barreiro, V. Peña.

Subtidal (13 m), maerl bed, Ons, Ría de

SANT-Algae 31423

Pontevedra, Galicia, Spain, 07/04/2011. Coll.

I. Bárbara, R. Barreiro, V. Peña.

Subtidal (13 m), maerl bed, Ons, Ría de

SANT-Algae 31424

Pontevedra, Galicia, Spain, 07/04/2011. Coll.

I. Bárbara, R. Barreiro, V. Peña.

Subtidal (13 m), maerl bed, Ons, Ría de

SANT-Algae 31425

Pontevedra, Galicia, Spain, 07/04/2011. Coll.

I. Bárbara, R. Barreiro, V. Peña. 
L. nitorum

L. nitorum

L. nitorum

L. nitorum
VPF00482

VPF00388

LLG4596I

LLG4608A
MG648766

MG648770

MG648768

MG648772
MG648774 Subtidal (13 m), maerl bed, Ons, Ría de

Pontevedra, Galicia, Spain, 07/04/2011. Coll.

I. Bárbara, R. Barreiro, V. Peña.

Subtidal (11 m), maerl bed, Cíes, Ría de Vigo, SANT-Algae 31428

Galicia, Spain, 07/04/2011. Coll. I. Bárbara,

R. Barreiro, V. Peña

Subtidal (15 m), La Herradura, Granada,

PC0144138

Spain, 19/09/2012. Coll. Le Gall, L., V. Peña.

Subtidal (15 m), La Herradura, Granada,

PC0144151

SANT-Algae 31426

Spain, 19/09/2012. Coll. Le Gall, L., V. Peña.

Additional sequences analysed

Lithophyllum bathyporum

KR736255

Brittany, Atlantic France

\section{L. bathyporum}

KR733435

$-$

Galicia, Atlantic Spain

Lithophyllum byssoides

Cádiz, Atlantic Spain

L. byssoides

JQ896252

$-$

JQ896251
Galicia, Atlantic Spain 
Lithophyllum dentatum (Kützing) Foslie

Lithophyllum hibernicum

L. hibernicum

L. hibernicum

L. hibernicum

L. hibernicum

L. hibernicum

Lithophyllum impressum

Lithophyllum incrustans

L. incrustans

L. incrustans

L. incrustans

L. incrustans

Lithophyllum orbiculatum

Lithophyllum pustulatum (J.V.Lamouroux) Foslie

$\begin{array}{rrl}\text { KR708623 } & \text { KR708611 } & \text { Sitges, Mediterranean Spain } \\ \text { KR708622 } & \text { KR708594 } & \text { Ireland } \\ - & \text { KR708614 } & \text { Cornwall, UK } \\ \text { KR733526 } & - & \text { Brittany, Atlantic France } \\ \text { KR733530 } & \text { KR736256 } & \text { Galicia, Atlantic Spain } \\ \text { KR733464 } & & \text { Port de Sète, Mediterranean France } \\ \text { KR733463 } & - & \text { Granada, Mediterranean Spain } \\ - & \text { JQ917416 } & \text { NE Pacific } \\ \text { KR708619 } & \text { JQ896237 } & \text { Ireland } \\ \text { KR708620 } & \text { JQ896238 } & \text { Brittany, Atlantic France } \\ \text { KR733470 } & - & \text { Galicia, Atlantic Spain } \\ \text { KR733480 } & & \text { Granada, Mediterranean Spain } \\ - & \text { KR708602 } & \text { Granada, Mediterranean Spain } \\ \text { KR708625 } & \text { KR708609 } & \text { Brittany, Atlantic France } \\ - & \text { KM407551 } & \text { Mediterranean Spain }\end{array}$


Lithophyllum stictaeforme (J.E. Areschoug)

Hauck

L. stictaeforme

Lithophyllum sp.

Lithophyllum sp.

Lithophyllum sp3

Porolithon onkodes (Heydrich) Foslie

Spongites agulhensis Maneveldt, E. van der

Merwe \& P.W.Gabrielsons

Spongites hyperellus (Foslie) D.L.Penrose

Uncultured Corallinales
KM407553

Mediterranean Spain

KM407554 Mediterranean Spain

KJ418414 Louisiana, USA

KJ418415 Louisiana, USA

MF133359

GQ917289

Galicia, Atlantic Spain

New Caledonia

KT184812

South Africa

GQ917495 Australia

GQ917452 Vanuatu 


\section{Figure legends}

Figs 1-9. Lithophyllum nitorum. 1. Holotype specimen (voucher US 70-10B). 2, 3, 5-7. Crustoses specimens overgrowing dead maerl (vouchers SANT-Algae 31427, 31426, 31424, 31425 and 31428, respectively). 4. Crustose specimen overgrowing pebble (voucher SANT-Algae 31421). 8. Crustose specimen overgrowing fragment of fishing line (voucher PC0144138). 9. Crustose specimen overgrowing cobble -arrow- (voucher PC0144151).

Fig. 10. Phylogenetic tree inferred from ML and BI analyses of $p s b A$ sequences of Lithophyllum recorded from European coasts, and highest similarity matches found in GenBank (> 94\%). In bold, holotype of Lithophyllum nitorum and other Lithophyllum species corroborated by type collections. Stars indicate species names linked to type specimens by DNA sequences; quotation marks for species names based on morphoanatomy or from topotype material (i.e. L. impressum). Bootstrap ML values $>60 \%$ and posterior probabilities $>0.60$ from Bayesian inference are shown for each node. Spongites agulhensis and S. hyperellus from the Southern Hemisphere were used as outgroup.

Fig. 11. ML tree inferred from DNA barcode (COI-5P). In red colour, recent collections resolved conspecific with the holotype of Lithophyllum nitorum, and their geographical location in the European coasts. Stars indicate species names linked to type specimens by DNA sequences; quotation marks for species names based on morpho-anatomy. Bootstrap values $>60 \%$ are shown for each node. Porolithon onkodes (subfamily Metagoniolithoideae, Corallinales) was used as outgroup.

Figs 12-18. Lithophyllum nitorum. 12-13. Surface of specimens bearing some markedly protruding uniporate conceptacles and with white rims (vouchers SANT-Algae 31424, PC0144151). 14. Vertical section showing adherent crust with monomerous construction 
-arrow- (voucher SANT-Algae 31426). 15. Vertical section showing cortical cells of contiguous filaments laterally aligned, and joined by secondary pit connnections -arrows; lumen cells containing inclusions usually interpreted as floridean starch (voucher SANT-Algae 31421). 16-17. Vertical section showing 1-2 layers of mostly flattened epithallial cells (e), and subepithallial cells (s) as short as or shorter than cells subtending them (voucher SANT-Algae 31428). 18. Surface view showing uniporate conceptacles markedly protruding (voucher SANT-Algae 31422).

Figs 19-22. Lithophyllum nitorum. 19. Vertical section showing likely spermatangial uniporate conceptacle, empty and buried (voucher SANT-Algae 31426). 20. Vertical section showing uniporate sporangial conceptacle containing tetrasporangia zonately divided -arrows- and small columella -c- (voucher SANT-Algae 31421). 21. Detail of pore canal of uniporate tetrasporangial conceptacle tapering to surface (voucher SANTAlgae 31421). 22. Vertical section showing old, empty uniporate conceptacles buried and not infilled (voucher SANT-Algae 31428). 


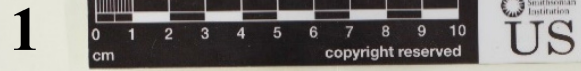

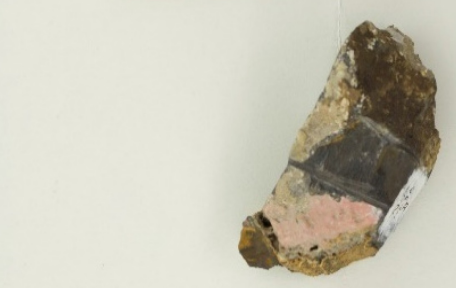

4

7

$0.5 \mathrm{~cm}$

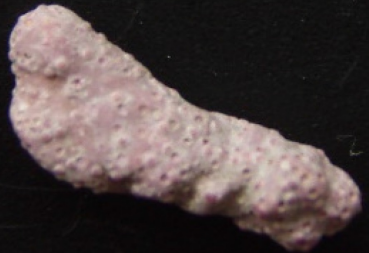

6

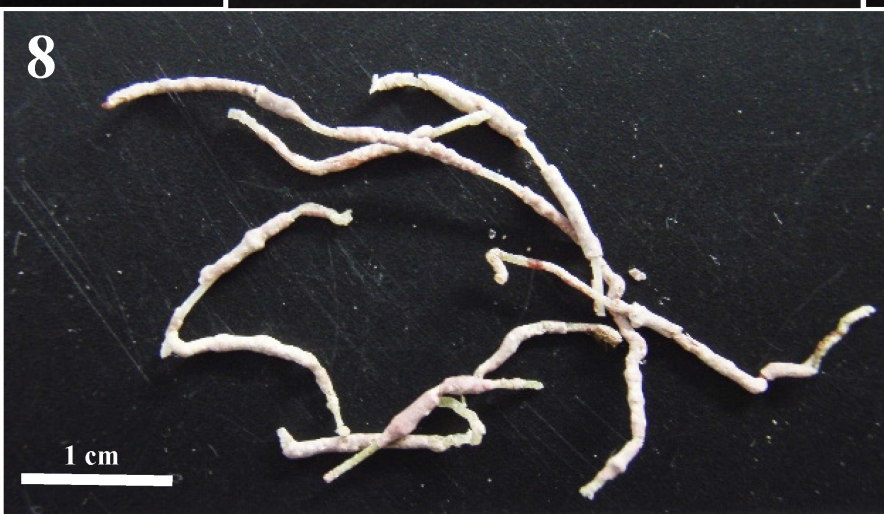

9

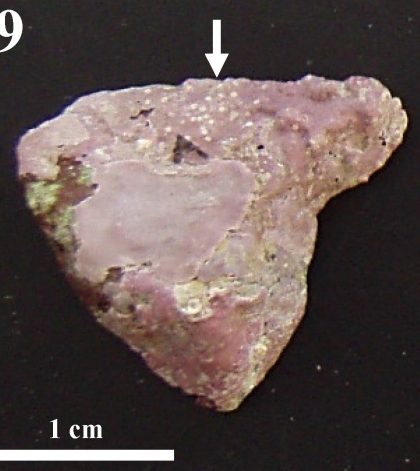




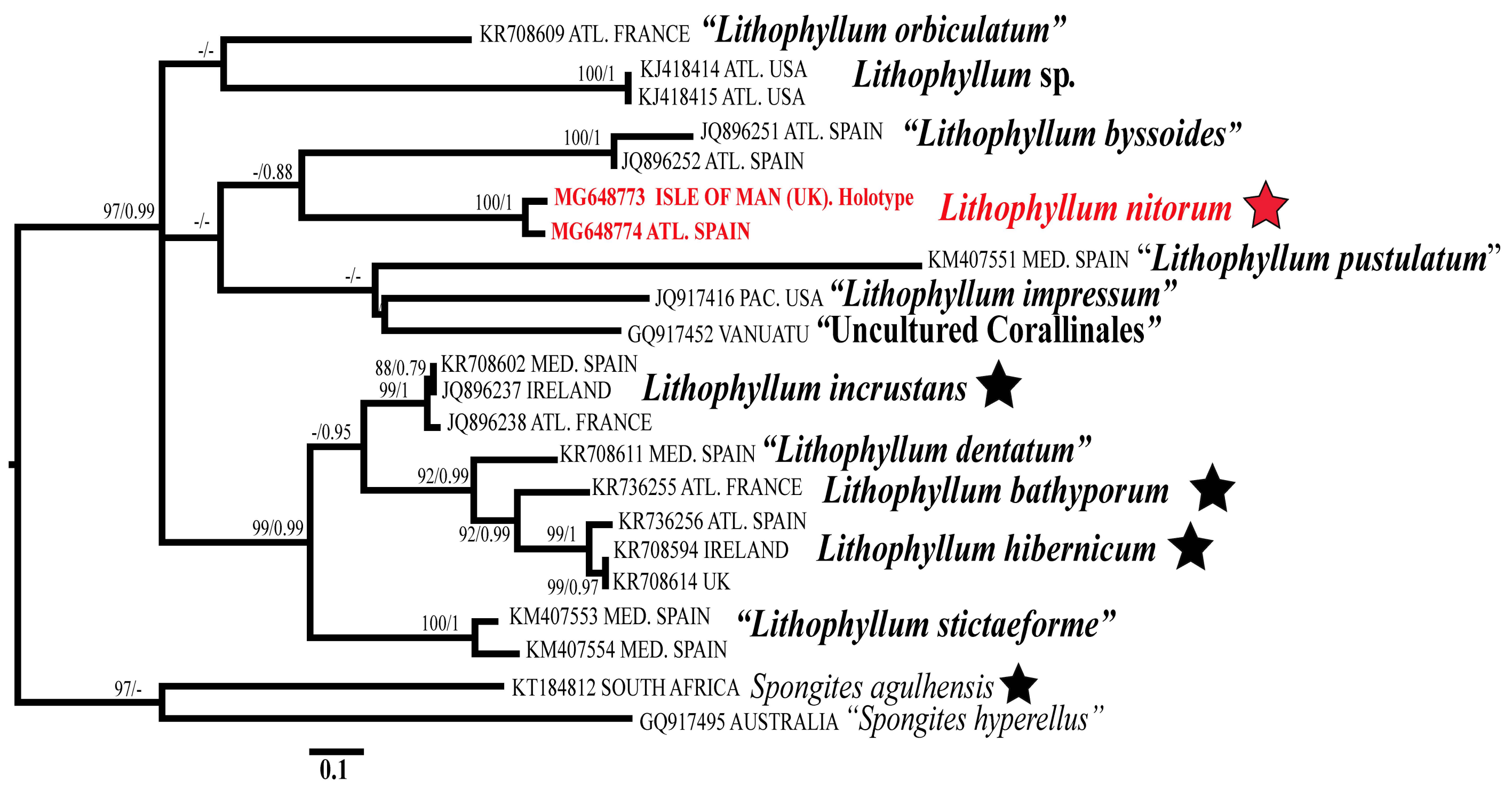




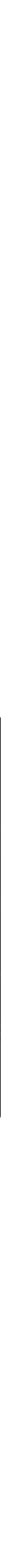



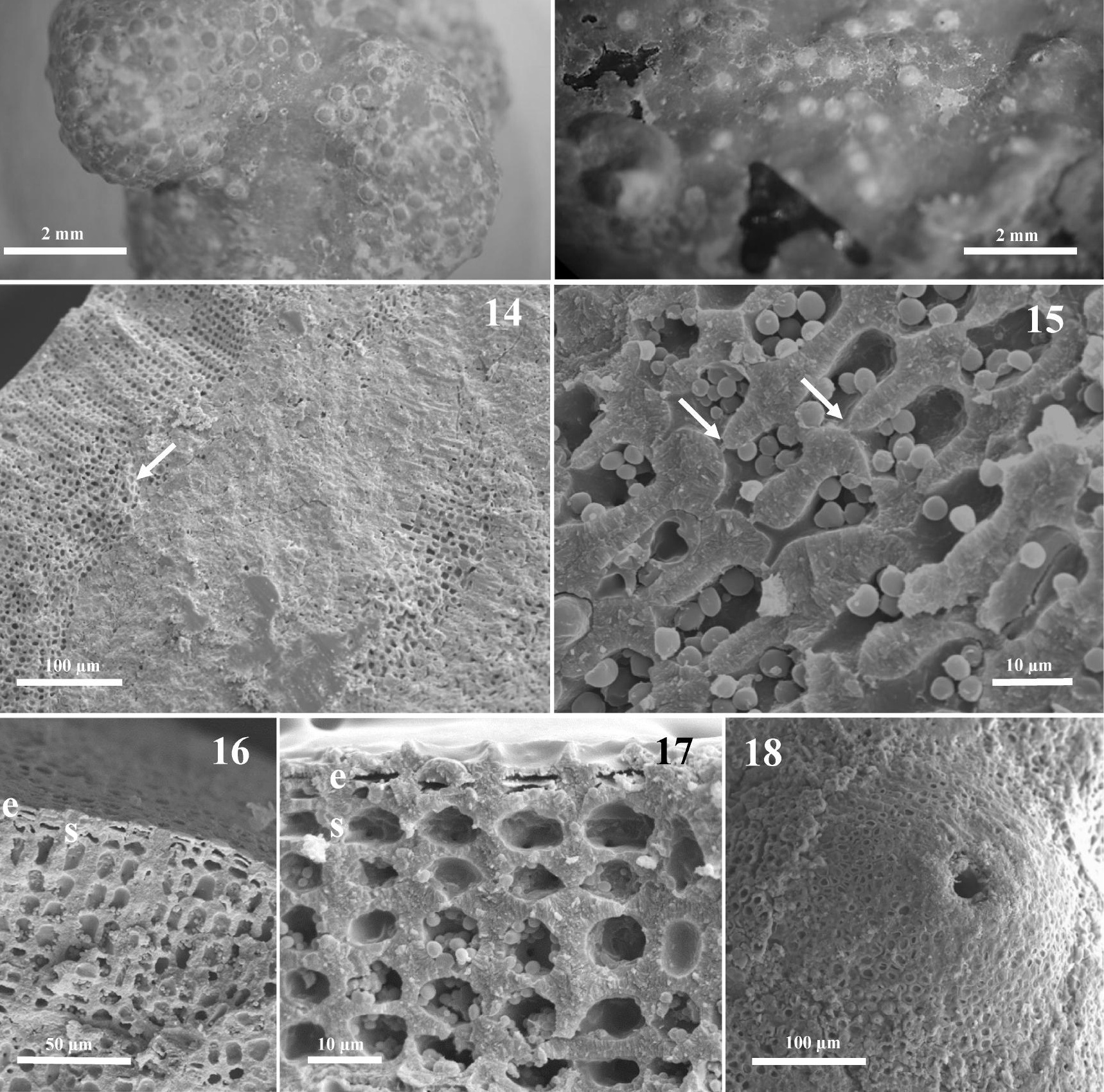